\title{
Seweryna Wysłouch \\ Od obrazu do sentencji. O grafice Sławomira Mrożka
}

ABSTRACT. Wysłouch Seweryna, Od obrazu do sentencji. O grafice Sławomira Mrożka [From the picture to a maxim. On graphic art of Sławomir Mrożek]. "Przestrzenie Teorii” 3/4, Poznań 2004, Adam Mickiewicz University Press, pp. 115-135. ISBN 83-232-1454-9. ISSN 1644-6763.

The author analyses co-existence of visual and language signs in Mrożek's drawings. Because of the kind of mutual relations, seven types of signs are distinguished. These are: 1 . visual autonomous signs; 2 . comic strips (stories in drawings); 3 . iconic multimeaning sign; 4 . iconic sign - interpreting of the language sign; 5. language sign - interpreting of iconic sign; 6 . language sign reduced to the plan of expression; 7 . iconic sign as a pretext to introduce language communication. The analysis shows the relational character of language signs in heterogenic communications and vast possibilities of iconic signs which, apart from conveying simple information, are capable of interpreting concepts and ridicule mechanisms of language manipulation. It also allows to speak about the evolution of Mrożek's work.

W społecznej świadomości Sławomir Mrożek istnieje głównie jako dramaturg i prozaik, stosunkowo niedawno przypomniano początki jego artystycznej działalności z lat 50. jako rysownika „Szpilek” i „Przekroju”, a w ostatnim dziesięcioleciu - „Gazety Wyborczej” i „Rzeczypospolitej”. Festiwal Stawomira Mrożka $w$ Krakowie (1990), a przede wszystkim wystawy rysunków w Gdańsku (1997) i Warszawie (1998) pokazały Mrożka inaczej. Oprócz wydawnictw okolicznościowych ${ }^{1}$ opublikowano wybory prac graficznych autora Postępowca oraz kilka tomów starannie przygotowanej przez wydawnictwo słowo/obraz terytoria edycji zebranej jego rysunków ${ }^{2}$. Jakby na potwierdzenie słów autora, który podkreślał, że nie ma wykształcenia plastycznego $i$ jest $\mathrm{w}$ tej dziedzinie amatorem ${ }^{3}$, jego grafika stała się przedmiotem refleksji literaturoznawczej. Daniel Ge-

1 Zob. Mrożek w Gdańsku, red. J. Ciechowicz, Gdańsk 1998; Mrożek. Rysunki dawne $i$ nowe. Katalog wystawy $w$ Muzeum Karykatury $w$ Warszawie, red. A. Rozwadowska i A. Kordela, Gdańsk 1998.

2 Zob. S. Mrożek, Rysunki, Kraków 1990; tegoż, Rysunki wybrane, wybór J. Górski, S. Rosiek, Gdańsk 1997; tego ż, Rysunki zebrane: t. 1 Od slużby postẹpowi do „Postępowca", oprac. A. Rozwadowska i S. Rosiek, Gdańsk 1997; t. 2 Polska w obrazach $i$ inne polskie cykle, oprac. S. Rosiek, Gdańsk 1998; t. 3 Pamiętnik. Ucieczka na poludnie, oprac. A. Rozwadowska, Gdańsk 2000; t. 4 Przez okulary 1960-1964, oprac. S. Rosiek, Gdańsk 2002 [edycja została zaplanowana na 7 tomow]. Cytowane przykłady pochodzą z wyżej wymienionych zbiorów. Za udostępnienie rysunków uprzejmie dziękuję Wydawnictwu słowo/obraz terytoria.

${ }^{3}$ Zob. Staram się uczciwie spelniać zamówienie. Rozmowa ze Slawomirem Mrożkiem w: S. Mrożek, Rysunki zebrane, t. 1, s. 229. 
rould ${ }^{4}$ i Anna Rozwadowska ${ }^{5}$ podkreślali integralność dzieła Mrożka, zbieżność działalności plastycznej z literacką, wykorzystywanie tych samych motywów, tematów, nieustanne zmagania ze stereotypem, a także „językowy" charakter jego pomysłów. Tymczasem autor mówi o wyobraźni wizualnej i obserwuje u siebie „przewagę widzenia nad myśleniem"6. Fałszywa świadomość artysty czy - błędny trop dla badaczy? A może problem jest głębszy, dotyczy nie tylko grafiki Mrożka, ale wzajemnych relacji znaków ikonicznych i językowych? W szkicu Obraz $j$ stowo autor Postępowca wypowiedział się na ten temat, dyskredytując wartość intelektualną obrazu:

Wszędzie tam, gdzie chodzi o informację na temat akcji, obraz jest niezastąpiony. Na przykład instrukcje na temat: jak obsłużyć armatę (lub jakąkolwiek inną maszynę) - łatwiej przekazać obrazem niż opisem. Natomiast w sprawie myślenia obraz jest bezsilny. Informację na temat: co myślę o obsługiwaniu armaty - trudno przekazać inaczej, jak słowami?

Potraktujmy więc jego rysunki jako swoiste laboratorium, w którym „spotykają się” znaki wizualne i językowe. Sprawdźmy „bezsilność obrazu" i sposoby koegzystencji znaków w heterogenicznych komunikatach. W jakim kierunku ewoluuje grafika Mrożka?

\section{Znak ikoniczny i znak językowy}

Znak ikoniczny (wizualny) tradycyjnie definiowany jest jako znak, w którym znaczenie wynika $\mathrm{z}$ naturalnego podobieństwa do oznaczanego przedmiotu. Konsekwencją „naturalistycznej” koncepcji znaku było przekonanie, że jego mimetyczny charakter uniemożliwia przekazanie bardziej skomplikowanej informacji, formułowanie refleksji autotematycznej czy budowanie metafory ${ }^{8}$. Jednak szczegółowe badania pozwoliły zweryfikować te poglądy. Mieczysław Wallis w obszernej rozprawie $O$ znakach ikonicznych ${ }^{9}$ zwrócił uwagę na ich wieloznaczność i różny stopień podobieństwa do przedmiotu. Mówił o znakach bogato wyposażonych i o skrajnie uproszczonych, pokazywał, że mogą one stracić swój ikoniczny charakter i zmienić się w nieprzedstawiający ornament. Erich H. Gombrich akcentował rolę konwencji w odbiorze, podważając tym

${ }^{4}$ Zob. D. Gerould, Mrożek i sztuka rysunku, w zbiorze: Mrożek i Mrożek, Kraków 1994.

${ }^{5}$ A. Rozwadowska, Mrożek rysownik, w zbiorze: Mrożek $w$ Gdańsku, op. cit.

${ }^{6}$ Zob. Staram się uczciwie spetniać zamówienie, s. 230-231.

${ }^{7} \mathrm{~S}$. Mrożek, Obraz i słowo, w: Małe listy, Kraków 1982, s. 98.

${ }^{8}$ Szerzej o tym piszę w książce Literatura a sztuki wizualne, Warszawa 1994 (rozdz.

Wizualność metafory).

${ }_{9}$ Zob. M. Wallis, O znakach ikonicznych, w: Sztuki i znaki, Warszawa 1983. 
samym naturalność znaków ikonicznych ${ }^{10}$. Najdalej w „rewizjonizmie” poszedł Umberto Eco. Traktował znaki ikoniczne nie jako proste odwzorowanie, ale jako rezultat operacji intelektualnej, w wyniku której uchwycone zostają tylko cechy istotne przedmiotu, przedstawione za pomocą określonych konwencji graficznych ${ }^{11}$. Tracą one w tym ujęciu "naturalny" charakter, stają się umowne i konwencjonalne, „bliższe” znakom językowym. Ten sposób myślenia znajdujemy także w pracy Janusza Lalewicza Przedstawianie $i$ znaczenie. Próba analizy semiologicznej rysunku ${ }^{12}$. Autor na przykładzie „ludzików” Mrożka pokazuje, że na rysunku rozpoznajemy człowieka bynajmniej nie ze względu na podobieństwo do istoty ludzkiej, bo takowego w rzeczywistości nie ma, ale ze względu na miejsce poszczególnych elementów w całości13. Pokraczne stwory z prostokątów, kółek, kropek i kresek nie są podobne do człowieka, ale je odczytujemy jako znak czlowieka, ponieważ nawiązując do konwencji graficznych, tworzą czytelny schemat postaci.

Znak ikoniczny (wizualny) zatem ukazuje (czy lepiej: wskazuje na) przedmiot i może to zrobić w sposób skrajnie uproszczony, schematyczny, odwołując się do znanych odbiorcy konwencji przedstawieniowych.

Natomiast znak językowy zaliczany jest do znaków symbolicznych, w których nie ma związku między znakiem a przedmiotem (ściślej: między planem wyrażania a planem treści) i w których znaczenie jest arbitralne i konwencjonalne. Znaczenie wyrazu ,jabłko" w żaden sposób nie wynika $\mathrm{z}$ jego budowy czy użytych $\mathrm{w}$ nim głosek. Zostało nadane arbitralnie i jest społecznie zaakceptowane. Ponadto znaczenie wyrazu nie wymaga odniesienia przedmiotowego i nie musi być konkretne, równie dobrze może być abstrakcyjne. Na przykład „złote jabłko” nie oznacza wcale owocu, ale doskonały interes. Zdolność przekazywania treści pojęciowych sprawia, że język uważany jest za najbardziej precyzyjne narzędzie myśli i najdoskonalszy środek międzyludzkiej komunikacji.

I oto na rysunkach Mrożka znak ikoniczny (lub ich zespół) spotyka się ze znakiem językowym (lub z rozbudowanym komunikatem: ze zdaniem czy nawet z dialogiem). Jak zauważył Stanisław Rosiek, „U Mrożka gra słowa i obrazu nieustannie się odnawia i przemienia"14. Dlatego proponuję ze względu na status znaku ikonicznego i rodzaj wzajemnych relacji między znakiem ikonicznym a znakiem językowym, wyodrębnić siedem typów znaków.

10 E. H. Gombrich, Sztuka i złudzenie. O psychologii przedstawiania obrazowego, przeł. J. Zarański, Warszawa 1981.

11 Pisalam o tym w książce Literatura i semiotyka, Warszawa 2001 (rozdz. Znak ikoniczny w koncepcji Umberta Eco - nowatorstwo i niekonsekwencje).

12 Zob. J. Lalewicz, Przedstawianie i znaczenie. Próba analizy semiologicznej rysunku, Gdańsk, 1995.

13 T'amże, s. 55-59.

${ }^{14}$ Zob. S.R. [S. Rosiek], Wstęp do Rysunków zebranych, t. 1, s. 5. 


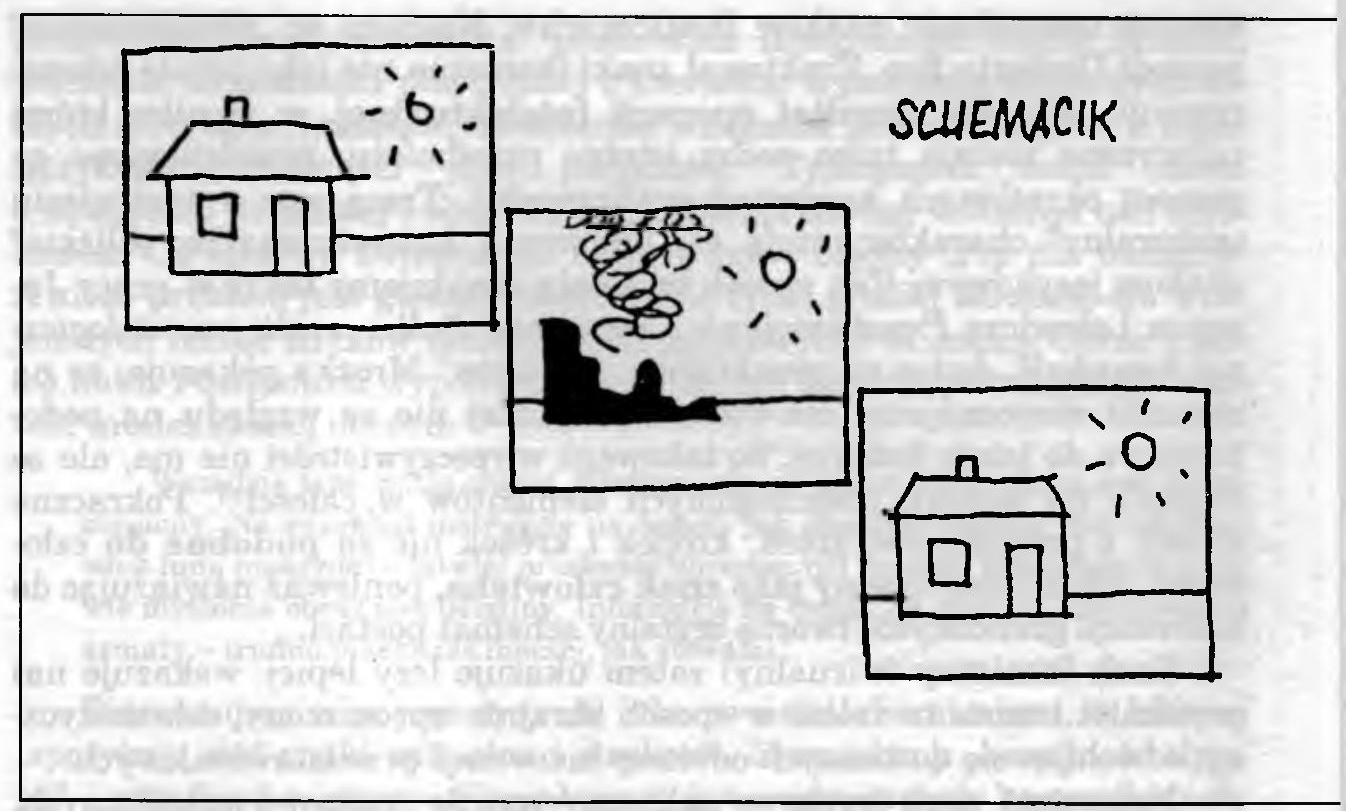

Są to:

1. znak wizualny autonomiczny;

2. historyjki obrazkowe;

3. znak ikoniczny wieloznaczny;

4. znak ikoniczny - interpretator znaku językowego;

5. znak językowy - interpretator znaku ikonicznego;

6. znak językowy zredukowany do planu wyrażania;

7. znak ikoniczny jako pretekst do wprowadzenia komunikatu językowego.

1. Znaki wizualne autonomiczne obywają się bez komentarza językowego i stanowią komunikaty samoistne. Debiut rysunkowy Mrożka (nagrodzony w 1950 r. na konkursie "Szpilek") przedstawia lisa ze strzelbą $w$ pysku przebiegającego drogę zdumionemu leśniczemu. Podobny charakter mają inne prace $\mathrm{z}$ tego okresu. Kelner w eleganckiej restauracji strzela ponad glowami gości do zająca (1950), ludzie dźwigają na grzbiecie słonie (1954). Przedstawione na rysunkach sytuacje są sprzeczne ze zdrowym rozsądkiem, nieprawdopodobne, absurdalne. Absurd wynika z zamiany ról postaci i zmiany funkcji przedmiotów (lis gra rolę myśliwego, człowiek - słonia). Komunikat wizualny jest rozbudowany (składa się na ogół z kilku znaków) i nie potrzebuje komentarza. Tego typu rysunki znajdują się także w Postępowcu, z tą jednak różnicą, że tam absurdalne pomysły mają dwie wersje: wizualną i językową. Stanowią 


\section{HISTORII POLSKI \\ (OD 1914)}
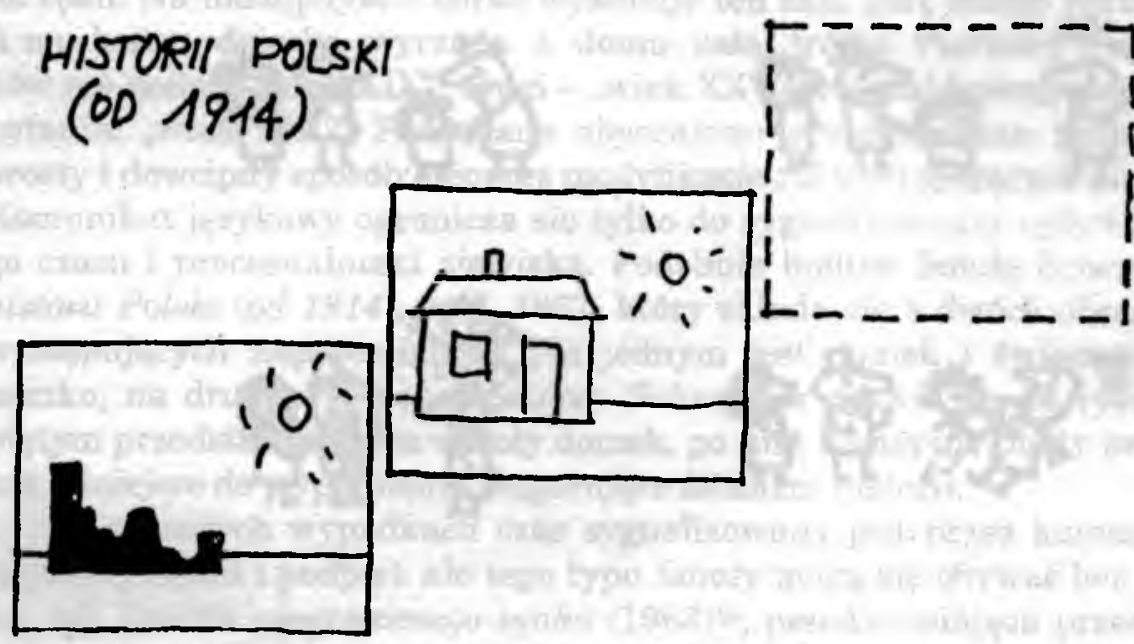

tematy zabawnych notatek, stylizowanych na język prasowych informacji. Tekst Co nowego $w$ zaświatach (1958) donosi, że anioły-stróże zostaną wyposażone w broń, ponieważ ich dotychczasowe metody zawiodły. I rzeczywiście, pilnujący chłopca anioł ma na ramieniu karabin $\mathrm{z}$ bagnetem. Rysunek jest całkowicie zrozumiały i nie wymaga słownych wyjaśnień. Dlatego można potraktować komunikat ikoniczny i komunikat językowy jako całości niezależne, dublujące tę samą informację (taka jest też cała seria 101 pożytków z jamnika). Bywa, że tekst językowy wpisuje absurd w określoną sytuację społeczną, wyostrzając w ten sposób jego satyryczną wymowę, np. samochód kryty strzechą został skomentowany notką pt. Tanio a swojsko, która podkreśla ludowy i narodowy charakter epokowego wynalazku.

2. Historyjki obrazkowe. Mrożek szlifował swój warsztat, korygował rysunki, tworzył z nich większe kompozycyjne całości jak cykl Polska $w$ obrazach (1957), składający się z wielu „tomów”, „rapsodów” i „opusów” czy Polak w Paryżu (1958). Kompozycje te stanowią coś w rodzaju tablic synchronicznych gromadzących dane na określony temat i nie wydają się z literackiego punktu widzenia interesujące. Ale wśród prac Mrożka są również historyjki fabularne, uwzględniające upływ czasu. Taką jest np. trzyczęściowa Ewolucja obyczajów, której bohaterami są ojciec, matka i córka z niemowlęciem. Na pierwszym obrazku ojciec gniewnym gestem, w obecności płaczącej matki, wyrzuca córkę z dzieckiem 
亩

嘉

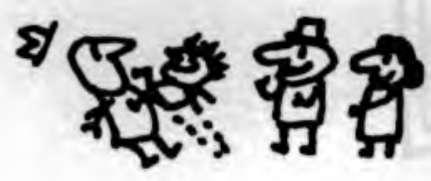

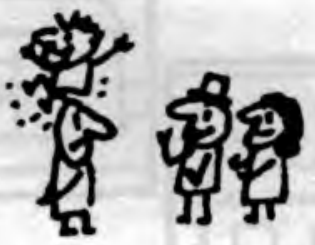

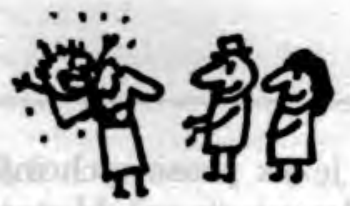
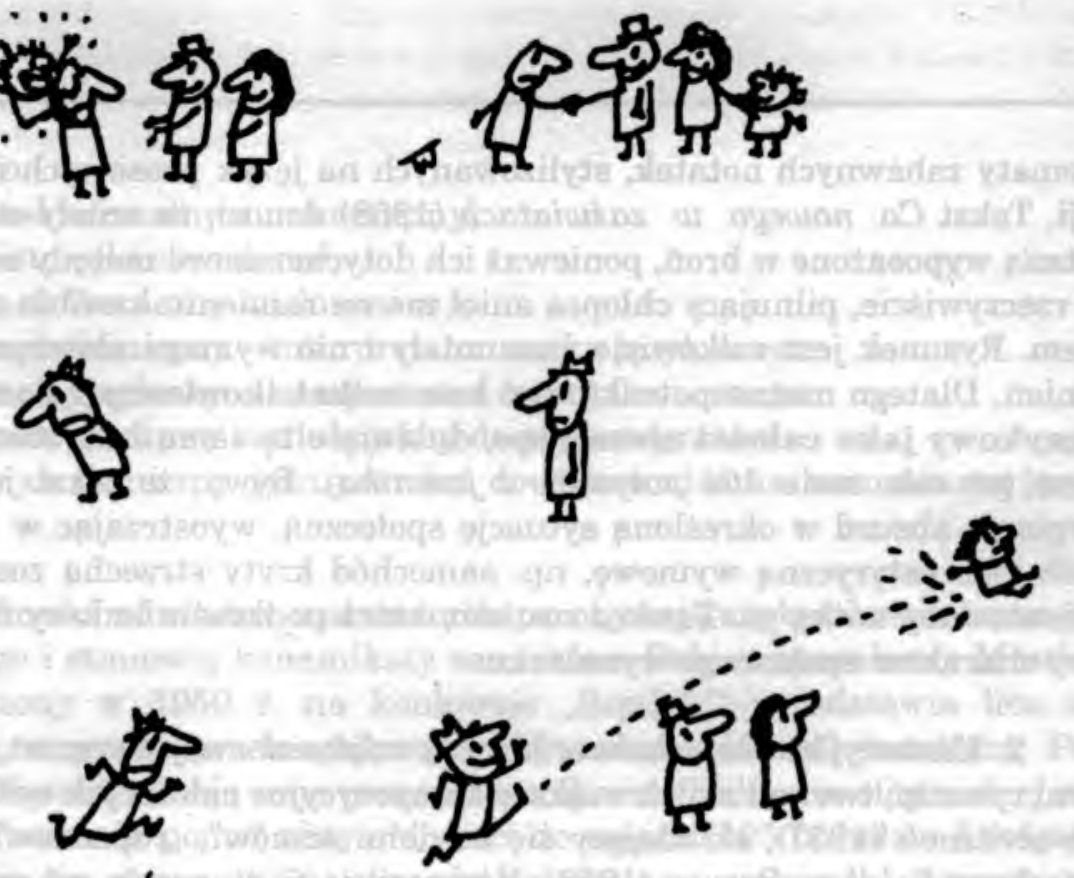
na ręku. Na następnym - córka wykonuje ten sam gest wobec rodziców. A na końcu dziecko wyrzuca $\mathrm{z}$ domu całą trójkę. Pierwszy z rysunków ma podpis „wiek XIX”, drugi - „wiek XX”, a ostatni kończy znak zapytania: „wiek XXI?” Przemiany obyczajowe przedstawione zostały w prosty i dowcipny sposób: poprzez modyfikację ról występujących postaci. Komunikat językowy ogranicza się tylko do sygnalizowania upływającego czasu i procesualności zjawiska. Podobnie buduje fabułę Schemacik historii Polski (od 1914), wyd. 1957, który składa się z dwóch obrazków występujących naprzemiennie. Na jednym jest domek i świecące słoneczko, na drugim - płonące ruiny. Schemacik urywa się na rysunku piątym przedstawiającym wesoły domek, po nim następuje pusty prostokąt - miejsce do wypełnienia, sugerujące fatalizm historii.

W opisanych wypadkach czas sygnalizowany jest przez komunikat językowy (tytuł i podpis), ale tego typu fabuły mogą się obywać bez języka, jak Zemsta niegrzecznego synka (1963) ${ }^{15}$, przedstawiająca przechodnia grzecznie pozdrawiającego znajomych, który zostaje zaatakowany przez niesfornego bachora przy aplauzie jego rodziców. Maltretowany na kolejnych trzech obrazkach, w końcu żegna się i odchodzi, by - po namyśle - podstępnie podbiec i dać solidnego kopniaka nieletniemu prześladowcy.

Bywa, że fabuły obrazkowe kończy językowa pointa. Pokazuje to historia podskakującego człowieczka, który skacze coraz wyżej, na trzecim rysunku wali głową w sufit, a na czwartym, już leżąc na podłodze, mówi: „Tak kończą się moje wzloty” (1979). Fizyczny wyraz radości (utrwalony zwrotem „skakać z radości”) zyskuje wykładnię daleko szerszą, metaforyczną, która sugeruje problemy duszy, a nie ciała. Komunikat językowy pozwala wykroczyć poza dosłowność sytuacji.

Konstruowanie fabuły nie wymaga komentarza językowego i dlatego wiele Mrożkowych historyjek go nie ma. Wymaga natomiast powtórzenia sytuacji $\mathrm{z}$ zaznaczeniem choćby minimalnej zmiany, którą odbiorca zinterpretuje jako wynik czasowego następstwa. Historyjki wykorzystują szerzej technikę komiksu (ruch zaznaczony linią przerywaną, dymki przedstawiające zwerbalizowane i niezwerbalizowane myśli bohaterów itp.). Komunikat językowy pełni tu funkcje szczególne. Pozwala uogólnić sytuację i nadać jej wymiar metaforyczny.

3. Znak ikoniczny wieloznaczny. Na rysunku Cesarz Franciszek Józef (1975) jeden i ten sam uproszczony znak graficzny ma trzy różne znaczenia: oznacza hełm z czasów Franciszka Józefa, postać tańczącą mazura oraz nagrobek samego Mrożka. Wszystkie te znaczenia wyjaśnia

15 Pod takim niefortunnym tytułem rysunek figuruje w katalogu Rysunków zebranych, t. 4, op. cit., pod nr 120 (s. 322). 


\section{Stor nxoy $M$ 7อ?}

(Anszeo new) nursta - Ya vNasooin sintyad WISnge tN 'aimures- 84T $N$ Stol WANzBay -aMAN nTVO UN YAzUN
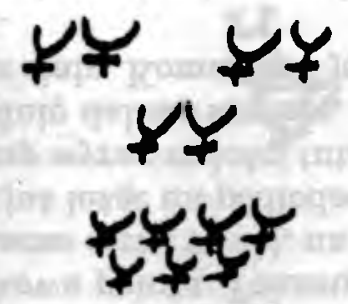

(ANO380 NULS) St8I ArYO OSBMON

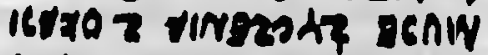
cheld heln niversalo $M$ there Yersionvyd zayszo

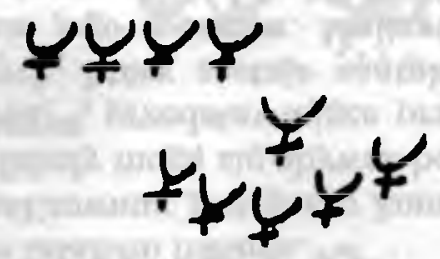


zamieszczony obok komentarz, w którym autor podaje nawet daty przeszłych i przyszłych wydarzeń. W ten sposób komunikat językowy zwraca uwagę na wieloznaczność znaku ikonicznego, który odbiorca może różnie odczytać (np. zobaczyć na rysunku pole bitwy i - u dołu - pointę w postaci nagrobka). Komentarz slowny jest tu niezbędny, stanowi integralna część komunikatu, w którym znaki wizualne same się nie tłumaczą.

4. Znak wizualny - interpretatorem znaku językowego. Można wyodrębnić tu dwie sytuacje: interpretację pojęcia poprzez obraz i udosłownienie metafory językowej.

a) Obraz interpretuje pojęcie. Jeden $\mathrm{z}$ najbardziej znanych rysunków Mrożka przedstawia trzy postacie: dużego kościotrupa z małym pokracznym stworkiem o wielkiej głowie, osadzonej na patykowatych nogach, oraz ludzika mówiącego: „Przyszedł strukturalizm z surrealizmem”. Komunikat słowny podsuwa odbiorcy pojęcia, które znajdują interpretację wizualną. Bez niego rysunek odczytywalibyśmy zgodnie $\mathrm{z}$ tradycją jako alegorię śmierci, która zabiera dziecko. W kontekście zacytowanej wypowiedzi szkielet kostny okazuje się celową i funkcjonalną strukturą, a mały potworek - surrealizmem.

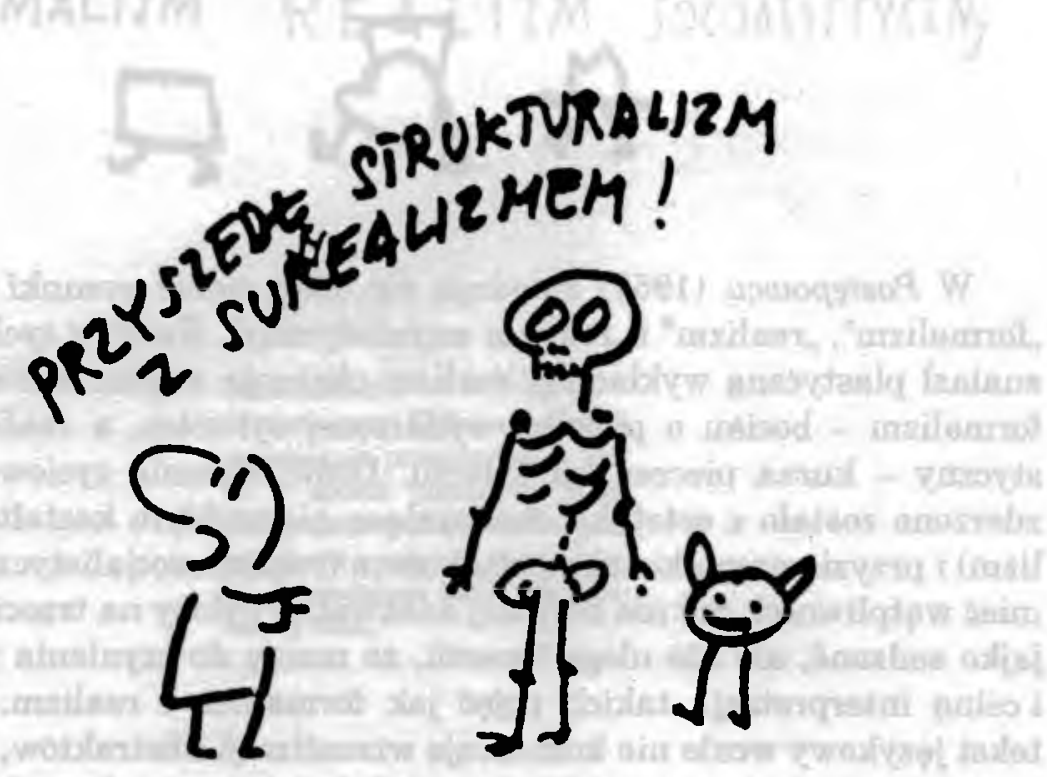


Mrożek lubi interpretować graficznie pojęcia abstrakcyjne i takich przykładów w jego dorobku jest więcej. Na rysunku maszeruje dziarsko człowieczek mówiąc: „Do psychoanalizy”, a poniżej w odwrotną stronę kroczą osobno: kapelusz, nogi i idąca na rękach głowa. Widać jak na dłoni efekt seansu psychoanalitycznego - rozłożonego na elementy pacjenta, który świat widzi do góry nogami.
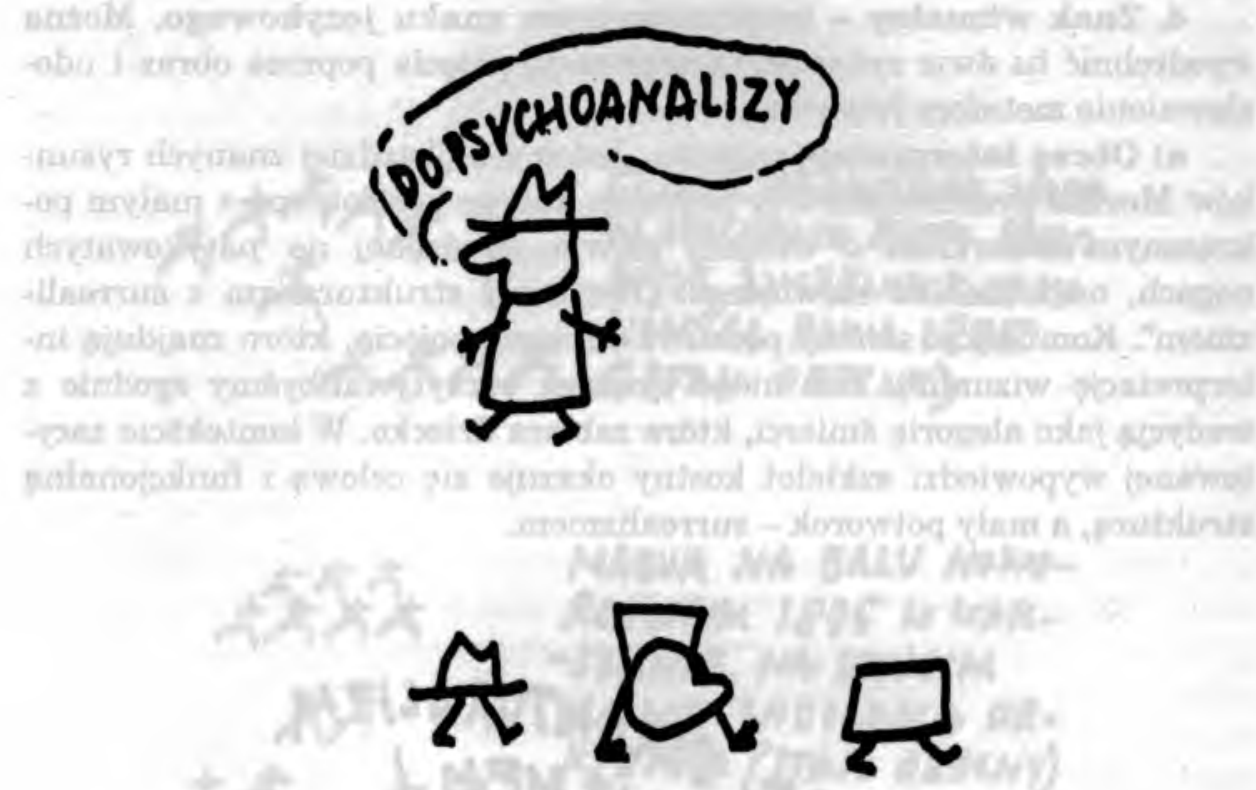

W Postępowcu (1957) znajdują się obok siebie rysunki podpisane: „formalizm”, „realizm” i „realizm socjalistyczny”. Każdy z tych terminów znalazł plastyczną wykładnię: realizm obrazuje zwykła kura $\mathrm{z}$ jajkiem, formalizm - bocian o pięknej, wydłużonej sylwetce, a realizm socjalistyczny - kurza pieczeń na talerzu. Doświadczenie życiowe (realizm) zderzone zostało $z$ estetyką, fascynującą niezwykłym kształtem (formalizm) i przyziemnym konsumpcjonizmem (realizm socjalistyczny). Można mieć wątpliwości, czy nie bardziej adekwatne byłoby na trzecim rysunku jajko sadzone, ale nie ulega kwestii, że mamy do czynienia z dowcipną i celną interpretacją takich pojęć jak formalizm i realizm. Dołączony tekst językowy wcale nie komentuje wizualizacji abstraktów, ale dostarcza im "ramy sytuacyjnej”. Nosi tytul Szkolnictwo i informuje o zatwierdzonych przez Ministerstwo pomocach dydaktycznych z zakresu teorii sztuki. 

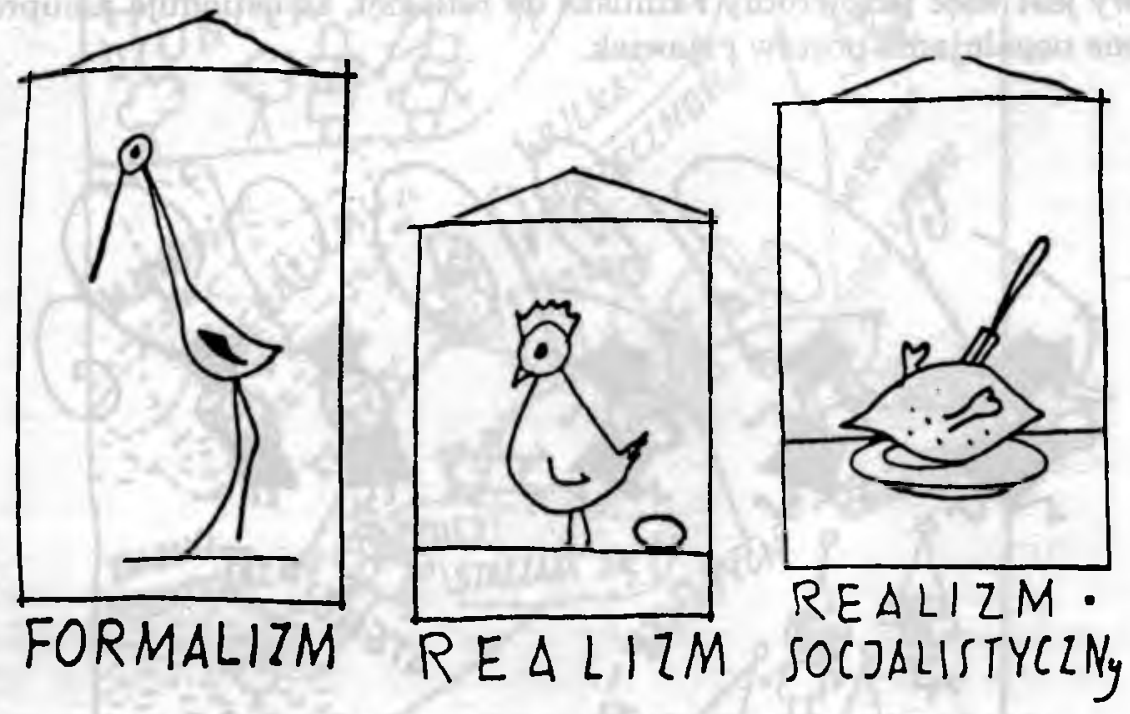

Szkolnictwo

Ministerstwo Kultury i Sztuki zatwierdzilo projekty tablic, które $w$ sposób poglądowy zapoznają dziatwę z podstawowymi pojęciami z zakresu teorii sztuki. Reprodukcje tablic zamieszczamy obok. 
Rysunek podpisany: Hastem bojowym Polaków byto „Bij, kto w Boga wierzy" przedstawia pięciu krakusów. Trzech biegnie $\mathrm{z}$ wyciągniętymi szablami, a dwaj stoją skromnie na boku, pod nimi zaś napis „ateiści”. Hasło bojowe potraktowane zostało jak sylogizm nie dopuszczający wyjątków: każdy, kto walczy, wierzy, i każdy, kto wierzy, walczy. Z tego prosty wniosek, że ten, kto nie walczy, musi być ateistą... Dowcip rysunkowy jest więc przewrotny i zmusza do refleksji, kwestionuje nieuprawnione uogólnianie postaw i zjawisk.

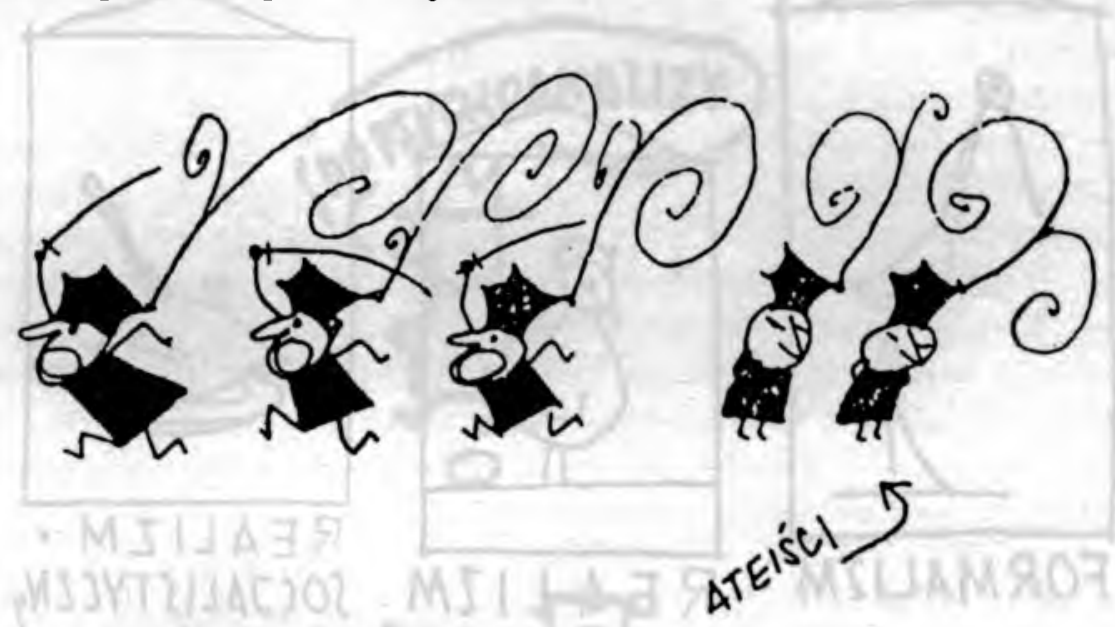

\section{HASEEM BOJOWYM POLAKOW BHLO "BIJ KTO W BOGA WIERZY"}

Omawiany typ znaków ikonicznych w sposób doskonały ilustruje poglądy Umberta Eco. Każdy znak jest bowiem wynikiem „operacji intelektualnej”, ukazuje charakterystyczne cechy pojęć abstrakcyjnych, wykorzystując do tego jakiś przedmiot konkretny, wybrany na podstawie analogii cech zewnętrznych lub swoich ukrytych funkcji. Ten typ znaków wizualnych nie może istnieć autonomicznie. Musi pojawić się znak językowy (interpretowany na rysunku termin), żeby odbiorca zrozumiał dowcip. I znak ten się pojawia w formie podpisu, dymku czy sentencji, przy czym lapidarności nie burzy nawet „rozgadana” poetyka Postępowca, który w takich wypadkach wprowadza jedynie „ramę okolicznościową".

b) Udosłownienie metafory językowej jest jednym z najczęstszych dowcipów Mrożka. A więc mamy rozpłaszczonego przez walec człowieczka, mówiącego: „płaski dowcip” (1979); „żelazny argument”, czyli chuligana walącego kogoś młotkiem w głowę ( $Z$ dyskusji o chuligaństwie). Na zasadzie dosłowności opiera się Poczet niektórych królów polskich (1957): 


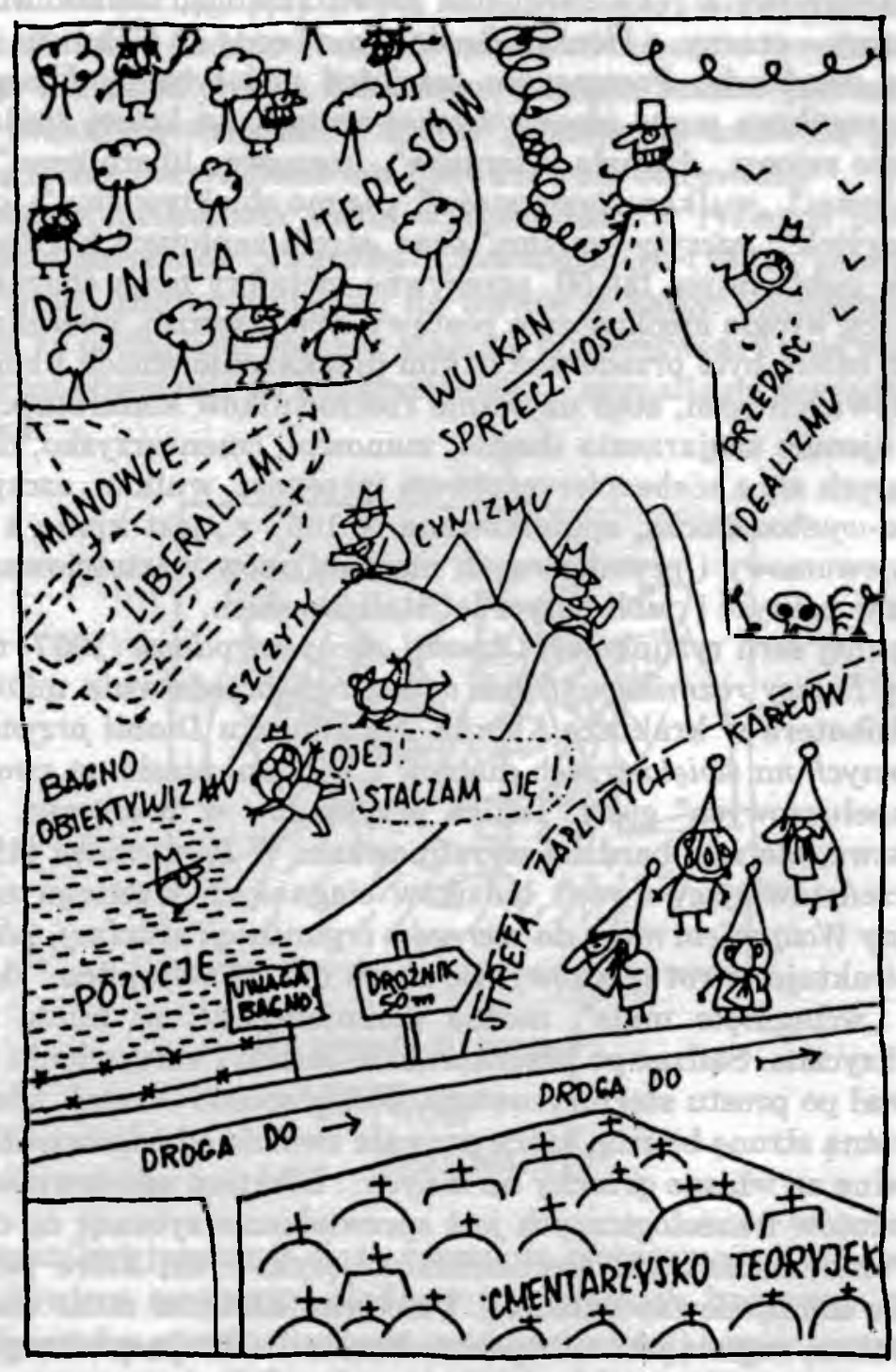

Uwaga! Nowość!

Jako pierwszy w historii zurnalistyki politycznej - "Postępowiec" zamieszcza dziś szczególową mapę ideowo-wychowawczą. 
August Mocny jedną ręką unosi nad głową sztangę, Leszek Biały jest biały, Czarny - czarny, a Henryk Brodaty ma brodę do ziemi itp. Ale są i ciekawsze przykłady. Postępowiec zamieścił pod tytułem Uwaga! Nowość! „Szczegółową mapę ideowo-wychowawczą”, na której znalazły się następujące rejony: „dżungla interesów”, „manowce liberalizmu”, „przepaść idealizmu”, „wulkan sprzeczności”, „bagno obiektywizmu”, „cmentarzysko teoryjek", „szczyty cynizmu” oraz „strefa zaplutych karłów”16. Popularne $\mathrm{w}$ publicystyce lat 50 . agresywne metafory mają charakter deprecjonujący wrogie ideologicznie postawy: obiektywizm, liberalizm, idealizm. Ich celem było przede wszystkim przekazanie emocji i sugerowanie negatywnych ocen, stąd używanie rzeczowników konkretnych konotujących ujemne skojarzenia (bagno, manowce, cmentarzysko, dżungla) lub wiążących się z niebezpieczeństwem (przepaść, wulkan, szczyt). $M a$ pa ideowo-wychowawcza, opublikowana w 1957 r., jest kpiną z socjalistycznej nowomowy i prymitywnych mechanizmów wartościowania stosowanych w polityce i publicystyce lat stalinowskich.

W słynnej serii rysunkowej Obyczaj, cechy narodowe (1957) rysunek podpisany Polacy rozmitowani byli $w$ koniach przedstawia miłosny pocałunek bohatera w krakusce i konia. Na rysunku Diabli przynoszq do nas znajomych na święta trzech diabłów $\mathrm{z}$ widłami niesie na swoich głowach „kapeluszowych” gości. Takich przykładów w twórczości Mrożka jest mnóstwo, ale są i bardziej wyrafinowane. W Pamiętniku (1958) rysunek przedstawiający dwóch ludzików ciągnących trzeciego za włosy i podpisany Wciqgnięto mnie do szeregów organizacji szkolnej, jak najdosłowniej traktuje zwrot językowy. Bo skoro nie ,ja wstąpiłem" do szeregów, ale „wciągnięto mnie”, można domniemywać, że miała miejsce przemoc fizyczna. Sądząc po przerażeniu w oczach i skrzywieniu ust, bohater został po prostu sterroryzowany. W ten sposób Mrożek zdemaskował wykrętną stronę bierną, która pozwala zwolnić od odpowiedzialności i zwalić winę za własne grzechy na innych... Efektem udosłownienia metafor i zwrotów frazeologicznych jest sprowadzenie sytuacji do czystego absurdu oraz demaskacja mechanizmów językowych, które pozwalają podstępnie manipulować odbiorcą. Ponieważ odbiorca musi zrozumieć grę z językiem, reguła jest tu wprowadzanie znaku językowego - najczęściej w formie podpisu pod rysunkiem.

5. Znak językowy - interpretatorem znaku ikonicznego. Chodzi tu o sytuację, kiedy komunikat wizualny znajduje zaskakującą wykładnię, zmieniającą sens całości. W 1956 r. w Postępowcu znalazł się rysu-

16 Aluzja do obelżywej nazwy AK została stonowana w innej wersji tego rysunku, która zawiera „krainę karlów” oraz pomija „manowce liberalizmu” i „cmentarzysko teoryjek" (zob. S. M rożek, Rysunki zebrane, t. 1, s. 144 oraz s. 212). 
nek kurka na dachu z językowym komentarzem: „W związku z pewnymi wypowiedziami / Bohater naszych czasów". Nazwanie przedmiotu wskazującego kierunek wiatru bohaterem naszych czasów jest satyrą polityczną atakującą wszystkich, którzy „umieją się ustawic”, „idą z wiatrem", a tych - jak wiadomo - w 1956 roku nie brakowało.

Podobny mechanizm został wykorzystany w rysunku podpisanym: Malarstwo narodowe: "Czwórka” Chetmońskiego (1957), przedstawiającym czterech zbirów grających na trawce w karty. Sarkastyczny tekst sprawia, że podmiejski obrazek staje się szyderstwem $\mathrm{z}$ wad narodowych i - poprzez odwołanie do Chełmońskiego - sygnalizuje degradację społeczeństwa.

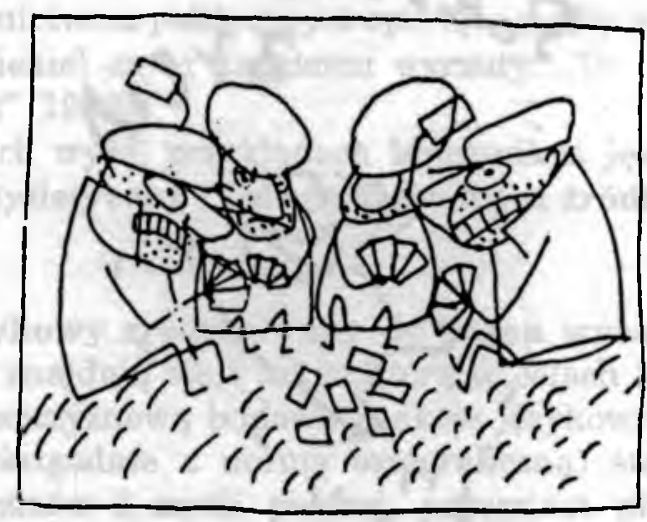

\section{MALAPSTWO NATODOWE: \\ "CZWORKA" \\ CHEKMON'SKESO}

Komunikat językowy służy często do piętnowania wad społecznych np. rozbawieni mężczyźni siedzący na wysokich barowych stołkach $\mathrm{z}$ wzniesionymi w górę kieliszkami opatrzeni zostali komentarzem: Tradycyjna postawa „w siodle” zachowała się do dzisiaj (1957).

Mechanizm satyry społecznej w opisanych wypadkach jest taki sam: scenka obyczajowa zostaje potraktowana jako exemplum wad narodowych. Komunikat językowy ją uogólnia i konfrontuje z przeszłością, pokazując tym samym w krzywym zwierciadle kontynuację narodowej tradycji. To właśnie sarkastyczny komentarz słowny pozwala Mrożka nazwać „szydercą". Bez niego moglibyśmy mówić tylko o „małym realizmie".

129 Od obrazu do sentencji. O grafice Sławomira Mrożka 
Ciekawe są sytuacje, kiedy komunikat językowy niespodziewanie zmienia sens rysunku. Przerażony bohater biegnie co sił $\mathrm{w}$ nogach $\mathrm{w}$ przeciwną stronę niż strzałka drogowskazu z napisem: „Do świetlanej przyszłości” (1982). Jego paniczna ucieczka kompromituje propagandowy slogan i - panującą ideologię. Oczywiście nie zawsze tego typu chwyty mają wymowę polityczną. Przykładem Radość życia - rozradowany człowieczek skaczący po leżącym. Tytuł uogólnia przedstawioną sytuację i sugeruje okrucieństwo natury ludzkiej, wyżywającej się na słabszym i bezbronnym.

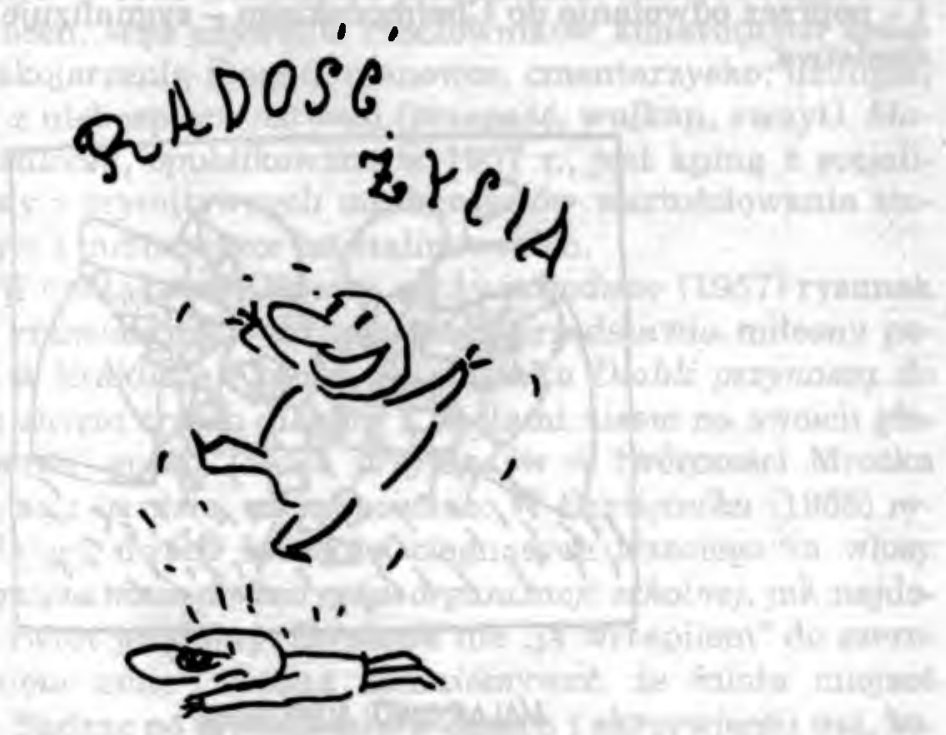

Mrożek wyciąga ostateczne konsekwencje $\mathrm{z}$ faktu, że w procesie komunikacji decyduje to, kto do kogo mówi. Wykorzystuje w dowcipach różne punkty widzenia i relacje między partnerami dialogu. $\mathrm{Na}$ dwóch „bliźniaczych” rysunkach charakteryzujących dawnych Słowian demaskuje tendencyjność ujęć: Wersja historyków rodzimych: dawni Stowianie (Polanie) - cisi, lagodni, ogoleni i - diametralnie różna - Wersja historyków obcych: Słowianie dawni, dzicy, niewychowani, zarośnięci. Albo komicznie kontrastuje rozmówców: siedząca w barze długowłosa kobieta ze skromnie spuszczonymi oczami mówi do zarośniętego mężczyzny, który ma minę zbója: „Jestem twoją duszą czystą i nieśmiertelną i nie mów do mnie rodczep się stara kurwo «". Wulgarny język zostaje zderzony ze stylem wysokim, zabawnie manifestując dualizm duszy i ciała. W celach komicznych wykorzystany zostaje też kontrast sytuacji dancingowej $\mathrm{z}$ aresztowaniem: milicjant kładzie rękę na ramieniu człowieka siedzącego przy barze, a on, nie odwracając się, mówi: „Dziękuję, nie tańczę”. 
Zaskoczeniem dla odbiorcy może być nie treść komunikatu, ale postać wypowiadająca. Rysunek zatytułowany Chodź, bijemy Darwina przedstawia - nie jak oczekiwalibyśmy - ideologicznych wrogów teorii ewolucji, lecz dialog dwóch małp, które nie chcą mieć nic wspólnego z człowiekiem. Cóż, w świecie Mrożka człowiek wcale nie jest lepszy od małpy...

Gdy w stadzie krów jedna woła: „Nie pchać się, bydło!” (1997), obelga kompromituje mówiącego, który zapomina, kim jest.

Styl wypowiedzi może kontrastować z przedstawioną sytuacją. Oto dwa diabełki o aniołku mówią „Nierogacizna” (1997). Termin z zakresu hodowli użyty zostal w odniesieniu do sfery niematerialnej (nawiązując zresztą do ludowych wyobrażeń duchów nieczystych). Podobny efekt powstaje, gdy słownictwem politycznym operuje upadły aniol. Oto jeden ze strąconych do piekieł czyni drugiemu wyrzuty: „Ty i twoje pomysły z zamachem stanu" (1990).

W cytowanych wyżej przykładach komunikat językowy wprowadza dysonans stylistyczny i jest niezawodnym źródlem komizmu sytuacyjnego.

6. Znak językowy zredukowany do planu wyrażania. Wśród rysunków Mrożka znajdują się i takie, które w celach komicznych wykorzystują dwupłaszczyznową budowę znaków językowych. Plan wyrażania (zapisany niezgodnie $z$ normą ortograficzną) staje się wyłącznie przedmiotem rozmów i myśli postaci, natomiast plan treści zostaje w ogóle pominięty. Oto na rysunku kobieta mówi do mężczyzny „rzegnaj” i odchodzi, a on zastanawia się: „rz”? Komizm jest tu podwójny, ponieważ błąd ortograficzny nie da się wyśledzić w żywej mowie i ponieważ mężczyznę po rozstaniu interesuje nie plan treści (rozstanie), ale jedynie plan wyrażania (język ukochanej). Ten sam typ dowcipu zastosował Mrożek w następującym dialogu ojca z synem: „Tato, co to jest chonor? „Przede wszystkim ortografia”. Odpowiedź ojca nie dotyczy meritum, dotyczy jedynie formy wypowiedzi ${ }^{17}$. Sęk $w$ tym, że pojęcie, o które chodzi, należy do świata wartości i w hierarchii aksjologicznej sytuuje się najwyżej - ponad wartościami hedonistycznymi i witalnymi. Stanowi człon świętej triady, wypisywanej na sztandarach (Bóg, Honor i Ojczyzna). I ta wartość w dowcipie Mrożka zostaje spostponowana, sprowadzona wyłącznie do ortografii, co można odczytać jako ironiczny znak naszych czasów.

17 Gwoli ścisłości należałoby dodać, że jeszcze obecnie można spotkać różnicę w wymowie głosek „h” i „ch” u ludzi pochodzących z Kresów Wschodnich, którzy „h” wymawiają dźwięcznie. Jednak ojciec z dowcipu Mrożka poprawia „ortografię”, a nie wymowę... 


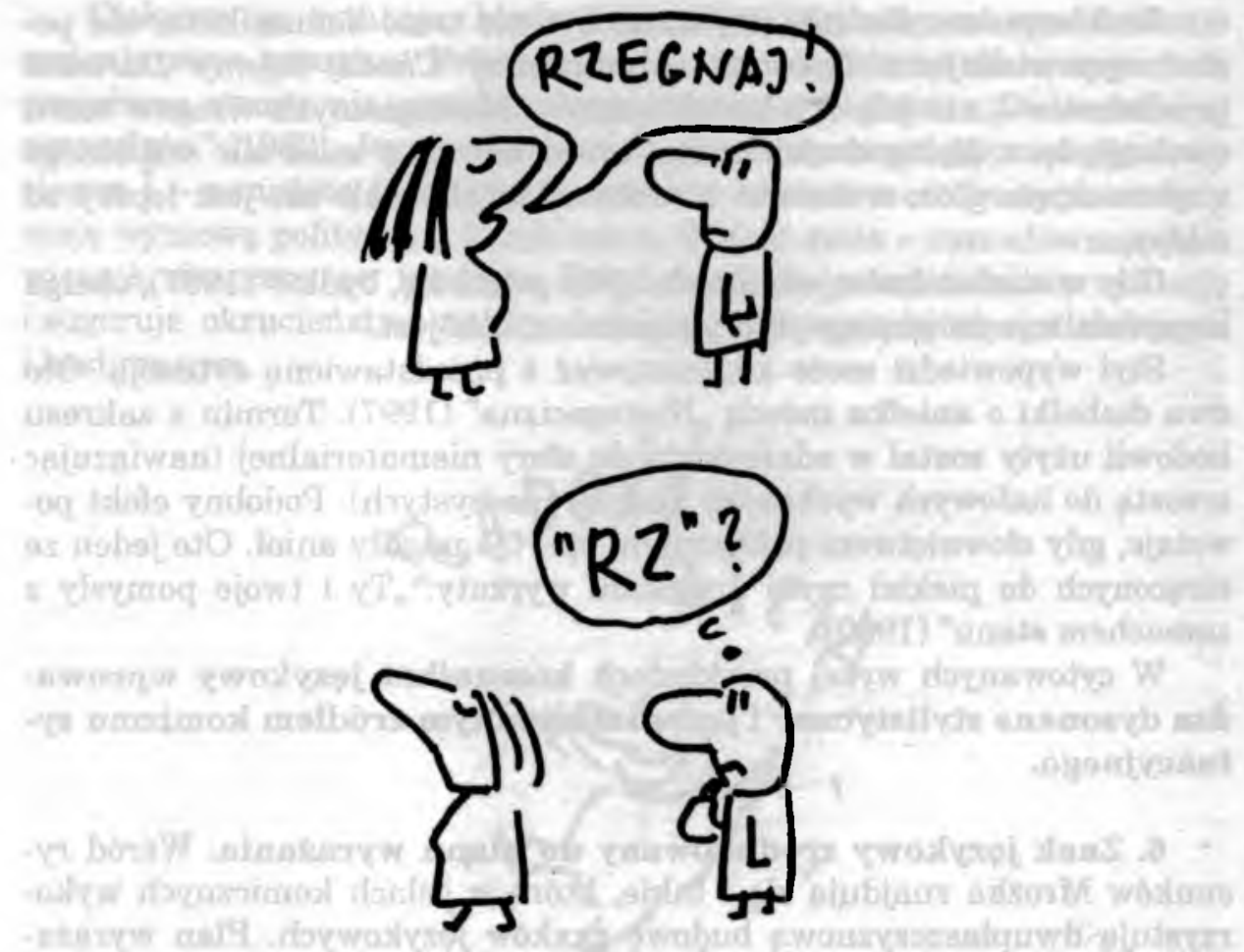

7. Znak ikoniczny jako pretekst. I wreszcie doszliśmy do sytuacji, w której komunikat językowy zdecydowanie dominuje, a znak wizualny odgrywa rolę podrzędną, stwarza ramę sytuacyjną dla wypowiedzi językowej. Taki charakter mają liczne dialogi syna z ojcem, szczególnie często wykorzystywane w latach 80. w „Szpilkach” i w 1. 90. w „Gazecie Wyborczej" (w cyklu Mrożek by night):

Tato, skąd się biorą dzieci? - Zapomniałem.

Tato, czy jest życie pozagrobowe? - Wyłącznie.

Tato, co było przed potopem? - Sucho.

Tato! Ziemia się trzęsie! - Dobrze jej tak!

Tato, co to znaczy interes społeczny? - To znaczy, że nie twój.

Tato, czy jestem przyszłością narodu? - Niestety.

Tato, przyszedł duży kapitał! - Powiedz mu, że dużego nam nie trzeba.

Tato, czy byłeś konfidentem gestapo? - Nie żadnym konfidentem, tylko mężem zaufania.

Tato, czego chciałbyś doczekać? - Postkretynizmu.

Tato, czy jesteś szpiegiem obcego mocarstwa? - Dlaczego zaraz obcego.

Tato, co to jest Rzeczpospolita? - To znaczy że nienadzwyczajna.

Tato, dlaczego pan Mrożek wraca do Polski? - Widocznie czegoś zapomniał. 
Rozmowy same się tłumaczą i wcale nie wymagają obrazka. Oparte są na dowcipie słownym, który jest bliski metaforze, ponieważ wykorzystuje niespodziewane konotacje, wieloznaczność wyrazów i kontaminacje związków frazeologicznych. Tego typu dialogów jest u Mrożka znacznie więcej np.:

To co z tego, że jestem gąsienicą? Ja wcale nie chcę zostać motylem, ja chcę zostać elektrotechnikiem.

Przepraszam, gdzie tu jest klozet publiczny? - Wszędzie.

Pan nie zmartwychwstaje? - Nie ma głupich.

Czy pan jest świętym starcem? - Tylko nie starcem, ty gnoju!

Daj pędzel, Maryś. Trza przerobić św. Józefa z powrotem na Marksa.

Ja jestem postmodernistą. A pan? - Postpolakiem.

Ale te komary dokuczają. - Bo one, panie, wszystkie są żydy i pederaści.

Dialogi zaskakują odbiorcę hierarchią wartości reprezentowaną przez bohatera, „szarego człowieka”, który czuje się przegrany w życiu społecznym i domowym. Oportunizm osłania sofistyką, myśli stereotypami. Ponury obraz współczesnego Polaka (który wcale nie chce być Polakiem) świadczy o głębokiej frustracji Mrożka i pesymistycznym stosunku do świata.

Najlepszym przykładem zdecydowanej autonomii komunikatu językowego jest drukowany w „Rzeczpospolitej” cykl pt. Kazania na górce. Stała rubryka, zawierająca aluzję do biblijnego Kazania na górze, przedstawia w większości jeden i ten sam rysunek: stojącego profilem ludzika z wyciągniętymi ku górze rękami. Kaznodziejska poza uzasadnia komunikat językowy, który ma kształt sentencji:

Małą szkodliwość społeczną poznaje się po wielkiej szkodzie prywatnej;

Trzecia droga to odnoga ideologa;

Kto daje, ten się nadaje;

Nie narzekaj na chamstwo. Ciesz się, że Sejm jest reprezentatywny;

Kopanie leżącego nie brudzi rąk, lecz niszczy obuwie;

Polityka do psychoanalityka!

Niech żyje ustrój drobnoustrojstwa;

Nie pytaj, czy Rząd ma wizję. On ma Telewizję⒙

Sentencje Mrożka nawiązują do tradycji Myśli nieuczesanych Stanisława Jerzego Leca, wykorzystują bowiem te same mechanizmy dowcipu językowego: grę słów, zbieżności brzmieniowe, rym, przekształcenia semantyczne, modyfikacje zwrotów frazeologicznych. Rysunek staje się dla

18 Zob. „Rzeczpospolita”, dodatek „+ Plus - Minus” (październik 2001 - maj 2002 r.). Ostatni „pożegnalny” rysunek Mrożka z tego cyklu ukazał się w „Rzeczypospolitej” 15/16 listopada $2003 \mathrm{r}$. 
czytelnika autorskim znakiem rozpoznawczym i pretekstem do wprowadzenia wypowiedzi językowej, natomiast nie wnosi nic nowego do interpretacji.

\section{Zakończenie}

Ernst H. Gombrich pisał, że poprawne odczytanie rysunku wymaga znajomości trzech elementów: kodu, kontekstu i podpisu ${ }^{19}$. Przegląd plastycznej twórczości Mrożka pozwala to twierdzenie skorygować. Niewątpliwie konieczna jest znajomość kodu (nie odczyta rysunków ktoś, kto nie zna konwencji graficznych i techniki komiksu). Natomiast kontekst ma charakter fakultatywny, zależy od gatunku wypowiedzi. Jest niezbędny w satyrze politycznej, która - jak twierdził Gombrich inaczej jest niema (jak np. Mrożkowa Mapa ideowo-wychowawcza), a także w „doraźnej” satyrze społecznej, wykorzystującej aluzje do konkretnych wydarzeń. W jednym z „kazań na górce” człowieczek na widok karetki pogotowia krzyczy: „Ratunku! Pogotowie Ratunkowe!”, co nawiązuje do skandalu w łódzkim pogotowiu, które miast ratować, uśmiercało pacjentów. Jeśli czytelnik o tym nie wie, nie zrozumie rysunku. W przeciwieństwie do konkretnej, satyra abstrakcyjna, aktualna zawsze i wszędzie, dotycząca natury i kondycji człowieka, obywa się doskonale bez znajomości kontekstu.

Podobnie rzecz się ma z podpisem czy szerzej - z komunikatem językowym, który może mieć formę podpisu, tytułu lub wypowiedzi bohatera. Historyjki rysunkowe nie wymagają słowa, dlatego komunikat językowy nie jest dla czytelnika konieczny. Jeśli się pojawi, zmienia sens globalny całości. Wprowadza dysonans stylistyczny i stanowi niezawodne źródło komizmu - sytuacyjnego i słownego. Znaki językowe maja więc charakter relacyjny, są związane ze znakami ikonicznymi i ich znaczenie zależy od roli, jaką pełnią w heterogenicznym komunikacie.

Rysunki Mrożka pokazują duże możliwości znaków ikonicznych, które zdolne są sygnalizować nie tylko schematyczny wizerunek postaci (płeć, wiek), emocje (radość, smutek), ruch - czy poprzez charakterystyczny szczegół wizualny (czapka krakowska) - narodowość. Mogą one przekazać samodzielnie informację, budować fabułę, a co najważniejsze, we współpracy ze znakami językowymi służą jako narzędzie interpretacji pojęć abstrakcyjnych i „rozbrajania” gazetowych sloganów. Najciekawsze i najbardziej płodne są więc różnorakie sposoby koegzystencji znaków ikonicznych i językowych. Znaki ikoniczne demaskuja mechanizmy manipulacji językowej; znaki językowe pozwalaja uogólnić przed-

19 Zob. E. H. Gombrich, Obraz wizualny, przeł. A. Morawińska, w zbiorze: Symbole i symbolika, red. M. Głowiński, Warszawa 1990. 
stawiona sytuację i nawiazać do tradycji. Finezyjne operowanie znakami ikonicznymi świadczy o wyobraźni plastycznej autora, jak również o tym, że obraz służy jako narzędzie refleksji, jako charakterystyczne exemplum i nie jest bezsilny w sprawie myślenia...

Czy można mówić o ewolucji grafiki Mrożka, zmierzającej w kierunku uwalniania obrazu od słowa? Moim zdaniem, nie. Ze względu na cykle rysunkowe $\mathrm{z}$ ostatnich lat bardziej uzasadniona byłaby teza odwrotna - o dażeniu do pelnej emancypacji słowa, uzyskującej ostateczny wyraz w sentencji. We wczesnej twórczości znaki wizualne charakteryzują się dużą autonomią. Rozbudowany komentarz językowy Postępowca wbrew pozorom odgrywa rolę podrzędną, dubluje informację przekazaną przez komunikat wizualny. Nie jest dla odbiorcy niezbędny. Ale w ciągu czterdziestu lat pracy twórczej komunikat ikoniczny stopniowo traci znaczenie na rzecz słowa, autor rezygnuje $\mathrm{z}$ historyjek obrazkowych i rysunek zaczyna traktować pretekstowo. Minimalizacje roli komunikatu ikonicznego potwierdza stosowana w grafice Mrożka technika komizmu. We wczesnych rysunkach dominuje komizm sytuacyjny, przedstawione są „historyjki” i „,scenki”, zaskakujące układy komunikacyjne, różne punkty widzenia i stanowiska bohaterów. Oczywiście, komizm sytuacyjny pociągał za sobą komizm słowny (dysharmonię stylistyczną). Ale w twórczości późniejszej, w rysunkach z lat 80. i 90 . (cykle Mrożek by night i Kazania na górce), gdzie komunikat językowy odgrywa dominującą rolę, komizm słowny niepodzielnie króluje (wykorzystywanie gry slów, homonimii, aluzji, rymu, zapisu wyrazów). Rysunki Mrożka ewoluują więc podobnie jak jego twórczość narracyjna z lat 90 ., która odchodzi od diagnozy rzeczywistości i zmierza w kierunku wielkiego uogólnienia. Ważne stają się nie doraźne zachowania, lecz uniwersalne reguły rządzące światem i one właśnie znajdują wyraz w aforystycznym stylu tej prozy ${ }^{20}$. Podobną prawidłowość obserwujemy w grafice autora Kazań na górce.

${ }^{20}$ Zob. A. Legeżyńska, Jak starzeje się Mrożek? w: Krytyk jako domokrq̨żca. Lekcje literatury $z$ lat 90, Poznań 2002. 